\title{
Effects of processing methods and packaging materials on the quality attributes of Suya meat
}

\section{Joshua Olanrewaju Olaoye, Obafemi Ibitayo Obajemihi, Temiloluwa Charity Metiboba}

\author{
Department of Food Engineering, Faculty of Engineering and Technology, \\ University of Ilorin, Ilorin, Nigeria
}

\section{Keywords:}

Suya

Grilling

Roasting

Glass jar

Aluminium foil

Yaji

\section{Article history:}

Received 14.10.2016

Received in revised form

11.11.2016

Accepted 30.12.2016

\section{Corresponding author:}

Olaoye Joshua Olanrewaju

E-mail:

jolanoye@unilorin.edu.ng

DOI: $10.24263 / 2310-1008$ -

2016-4-2-7

\section{Abstract}

Introduction. This study was conducted to determine the effects of processing techniques and packaging materials on the quality of Suya meat.

Materials and Methods. Grilling and roasting techniques were used to process lean beef meat each weighing $1.5 \mathrm{~kg}$. After processing, the samples were packaged in four different materials, Glass jar, Aluminium foil, Cling film and Paper up to a period of seven days and the proximate composition of the samples were analysed for ash, crude protein and fat. The moisture content of each sample was also determined in the laboratory. A $2 \times 5$ factorial experiment was designed to investigate the treatment combination of two methods of suya processing (grilling and roasting) with five packaging materials (Glass Jar, Aluminium foil, Cling film, Newsprints and a Control) in a completely randomized design with three replicates.

Results and Discussion.Findings showed that roasting and grilling techniques used in processing of Suya meat have effects on its quality. Results showed that the values of crude protein for roasting and grilling were $41.82 \%$ and $39.91 \%$ respectively while for fat the values were $9.92 \%$ and $8.36 \%$ respectively, which were significantly different from each other. Furthermore the results also showed that the packaging materials used in handling and preservation of the Suya meat samples have significant effect its quality. The results showed that samples stored in Glass jars, Aluminium foil, Cling film and Paper have average values of $6.42 \%, 6.24 \%, 5.45 \%$ and $5.28 \%$ of ash respectively; $40.18 \%, 38.79 \%, 38.46 \%$ and $37.92 \%$ of crude protein respectively; $10.69 \%, 9.38 \%$, $10.17 \%$, and $11.61 \%$ of fat respectively, and $8.06 \%, 8.17 \%$, $7.33 \%$ and $8.13 \%$ for moisture respectively. Analysis of Variance (ANOVA) table further revealed that the effect of packaging material is significant at $p \leq 0.05$ on the ash, crude protein, fat and moisture content of the stored Suya meat samples.

Conclusions. Processing techniques and packaging materials were found to have effects on the quality of processed and stored Suya meat. In order to have a high quality Suya meat, roasting technique should be used for processing and the products are to be handled and stored in Glass jars or Aluminium foils. 


\section{Introduction}

Suya is a form of processed stick-meat consumed by people in West Africa. It is produced from boneless meat hung on stick and spiced with peanut cake, salt, vegetable oil and other flavourings followed by roasting around a glowing charcoal fire [1]. It originated from the northern part of the country where the population of animals found in the area is large compared with other areas. The processed meat has a unique taste, flavour, colour and texture that distinguish it from other meats which are products of other processing techniques. Suya meat is produced from beef or mutton. There are three types of Suya namely, Tsire, Balangu and Kilishi. The process of preparation of Suya meat involves a few steps, first is the grounding of peanut. The shell and the skin are removed from the peanut before grinding into fine powder using mortar and pestle or crushed with a rolling pin. If the powder is oily; it is wrapped with an absorbent paper and squeezed for a minute or two. Next, the grinded pepper, garlic, ginger are stirred into the peanut powder and mixed properly. The meat is then cut into small sizes or thin sliced, dipped and rolled in a bowl containing the mixed peanut-spice and allowed to coat completely. The minced meat are then kept for thirty minutes or more for the peanut cake to stick to it after which the meat slices are threaded unto skewer and brushed with vegetable oil and roasted on the glowing charcoal fire for fifteen to twenty minutes [2].

Today Suya meat has gained wide popularity and it is been consumed by majority. Most of the processors of this meat were found in strategic locations and were people who does not have much formal education and as a result still uses traditional methods of handling, processing and packaging the products, which are considered to be unhygienic, unsafe and can result in rapid deterioration of the processed meat if not consumed within a short period of time. The processors have been accustomed to collecting old newspapers from different homes and using same to package Suya meat for their customers, which are considered to be dirty and dusty, also in some homes where chemicals were being used to control insects like cockroaches and mosquitoes, there is tendency of the chemicals being sprayed on the newspapers, which the chemicals when in contact with the meat and being consumed can poised serious health issues. Besides the fact that the use of old newspapers in packaging of Suya meat product does not give a good professional image to the processor, the printed inks on the papers contain pigments, colorants, binders, additives and photo initiators [3] which can be harmful to the health of the consumer.

Packaging does not only ensure that foods contains and maintains the amount and forms of the required ingredient and nutrients but also improves the sensory quality and colour stability. It has been demonstrated that food packaging can retard product deterioration, retain the beneficial effects of processing, extend shelf-life and maintain or increase the quality and safety of food [4]. Therefore it is important that food packaging materials should possess proper mechanical, thermal and optical properties for foods. In addition anti-microbial and barrier functions against gases, vapour and aroma are also important in food packaging materials [5]. Suya meats are to be stored between 50 to $60^{\circ} \mathrm{C}$ to disfavour the growth of microbes [6].

The principal roles of packaging are to protect food products from outside influences and damages, to contain the food, and to provide consumers with ingredient and nutritional information [7]. Packaging maintains the benefits of food processing after the process is completed, enabling food to travel safely for long distances from their point of origin and still be wholesome at the time of consumption. It is in view of these that this study was conducted to investigate the effects processing methods and packaging materials on the quality attributes of Suya meat. 


\section{Materials and methods}

The materials and equipment that were used to carry out this research and the basis for their selection and also some of their standard properties were discussed. This is with reference to existing packaging materials in Nigeria for processed suya meat $[8,9,10,11]$ and the details are as follow:

Glass Jar. A glass jars which are impervious to moisture, gases and microorganism were used. It has a density of $2.52 \mathrm{~kg} / \mathrm{m}^{3}$ [12].

Aluminum foil. Aluminum foil is used as the second packaging material with a thickness of $0.0065 \mathrm{~mm}$ with a specific gravity of 2.7 , melting point of $660^{\circ} \mathrm{C}$ and a thermal conductivity of $235 \mathrm{~W} / \mathrm{m} . \mathrm{K}$. The molecular structure of the metal provides a high performance barrier. The naturally occurring oxide acts as a shield in the presence of oxygen in the atmosphere which makes it to be corrosion resistant. It is chemically resistant when in contact with substances with in the $\mathrm{pH}$ scale of range 4-9. It is non-absorbent and proof against water, oil and grease and other liquids.

Cling film. A thin film of flexible transparent polymer that clings to itself and to food containers to form a tight seal, which offers strong tear resistance, it is highly impermeable to oxygen and water and also has excellent organoleptic properties which does not affect the taste of the product.

Paper (Newsprint). Paper made from thin material produced by pressing together moist fibres of cellulose pulp derived from wood and being dried into flexible sheets was used.

Processing Techniques. Two processing techniques were used in the preparation of Suya meat. These techniques were grilling and roasting. Two processing techniques are appropriate for meat conditioning and processing that can mitigate spoilage $[11,13]$.

Grilling Method. The grilling method for the Preparation of Suya meat was carried out at a Suya processor spot at Tanke Oke-odo, Ilorin, Kwara State, Nigeria. The process of preparation involved the following unit operations as earlier adopted by [13]. The procedure includes spice mixing, cleaning, size reduction, placing on grill, grilling and cooling.

Spice Mixing. The spices used in preparing the ingredient were purchased from specialized spice market. They included red pepper (Capsicum fructescens), Seasoning (Monosodium glutamate), Maggi (Levisticum officinales) Curry powder (Trigonella foenum), salt (Sodium chloride) and Yaji sauce.

Cleaning. 1.5 kilogram lean meat from beef was bought from the meat market and cleaned in a potable water to get rid of all dirt

Size Reduction. The meat was sliced into thin fillets manually by the use of a sharp edge of knife in order to remove undesirable materials and to increase the surface area 
Placing on Grill. The pieces of meat were placed on the grill and sprinkled with the ingredients and about $5 \mathrm{ml}$ of groundnut oil for grilling

Grilling (Heat Process). Grilling was achieved by the grill method where the pieces of meat were placed on the grill directly over a burning mass of charcoal and firewood. The meat pieces were allowed to stay on fire for about thirty minutes. The pieces of meat were turned and sprinkled with the ingredient and groundnut oil at regular intervals to avoid burning

Cooling. After the grilling process, the fillets of meat were cooled and sprinkled with Yaji sauce.

Roasting Method. The roasting method for the preparation of Suya meat was carried at the Food Science laboratory, Faculty of Agriculture, University of Ilorin following the processing steps highlighted by [13]. The process of preparation involved spice mixing, cleaning, size reduction, placement on oven rack, roasting and cooling.

Placement on Oven Rack. The pieces of meat were placed on the oven rack and sprinkled with the ingredients and about $5 \mathrm{ml}$ of groundnut oil for Roasting.

Roasting (Heat Process). Roasting was achieved by placing the thin fillet of meat on the oven rack and placed into the oven set at $150{ }^{\circ} \mathrm{C}$.After twenty minutes; the fillets of meat were flipped and sprinkled with the ingredients and vegetable oil. The total roasting time for both sides of the meat was fifty minutes.

The spices were mixed together in a specific proportion as described in Table 1.

Table 1

\section{Composition of Suya ingredient for grilling and roasting techniques}

\begin{tabular}{|c|c|c|}
\hline $\begin{array}{c}\text { Ingredient } \\
\text { constituents }\end{array}$ & $\begin{array}{c}\text { Proportion by weight } \\
(\mathbf{g})\end{array}$ & $\begin{array}{c}\text { Percent proportion in mixture } \\
(\mathbf{\%})\end{array}$ \\
\hline Curry powder & 10 & 9.01 \\
\hline Seasoning & 10 & 9.01 \\
\hline Condiment & 36 & 32.43 \\
\hline Red pepper & 5 & 4.50 \\
\hline Salt & 50 & 45.05 \\
\hline Total & 111 & 100.00 \\
\hline
\end{tabular}

Packaging. After Suya meat was prepared by the grilling and roasting method. Fifty (50) grams of Suya meat samples were weighed and filled into the packaging materials [14]. Each packaging material was labelled based on the design setup.

Experimental Design. A 2 × 5 factorial experiment was designed to investigate the treatment combination of two methods of suya processing (grilling and roasting) with five packaging materials (Glass Jar, Aluminium foil, Cling film, Newsprints and a Control). The factorial experiment was carried out in a completely randomized design with three 
replicates. The factors considered were five packaging materials and two treatment techniques for suya processing.

Methods for Evaluating Suya meat Quality. The packaged Suya meat was taken to chemistry laboratory, University of Ilorin for proximate analysis. The analysis was carried out at six hours interval for seven days.

Determination of Ash content of Suya meat. This was carried out as described by [15].The crucible was washed and dried in the oven and allowed to cool in a desiccator and weighed $2 \mathrm{~g}$ of Suya sample was weighed into an empty porcelain crucible which had been previously ignited and weighed. The Suya sample was then ignited over a hot plate in the fume cupboard to char organic matter. The crucible was placed in a muffle furnace maintained at a temperature of $600{ }^{\circ} \mathrm{C}$ for hours and transferred directly to a desiccator, cooled and weighed immediately. The calculation of the percentage ash was determined using equation (1).

$$
\% A s h=\frac{W_{3}-W_{1}}{W_{2}-W_{1}} \cdot 100
$$

where:

$\mathrm{W}_{1} \quad=$ Weight of empty crucible $(\mathrm{g})$

$\mathrm{W}_{2} \quad=$ Weight of crucible + suya sample $(\mathrm{g})$

$\mathrm{W}_{3} \quad=$ Weight of crucible + ash $(\mathrm{g})$

Determination of Moisture Content of Suya. This was carried out as described by [16]. $2 \mathrm{~g}$ of Suya sample was weighed into a Petri-dish which has been weighed previously, and then the Petri-dish was transferred into the oven at $101{ }^{\circ} \mathrm{C}$ until constant weight was achieved. The Petri-dish and the Suya sample were reweighed after cooling. The calculation of the percentage ash was determined using equation (2)

$$
\% M c=\frac{W_{2}-W_{1}}{W_{3}} \cdot 100
$$

where:

$M_{c} \quad=$ Moisture Content (\%)

$$
\begin{array}{ll}
\mathrm{W}_{1} & =\text { Weight of dried Petri-dish }(\mathrm{g}) \\
\mathrm{W}_{2} & =\text { Weight of Suya } \text { sample }+ \text { Petri-dish }(\mathrm{g}) \\
\mathrm{W}_{3} & =\text { Weight of dried Suya } \text { sample }(\mathrm{g})
\end{array}
$$

Determination of Crude protein of Suya. This was carried out as described by [15]. $2 \mathrm{~g}$ of Suya sample was mashed in a sterile laboratory type mortar and pestle. The mashed Suya sample was shaken with $100 \mathrm{ml}$ of $0.05 \mathrm{M}$ of sodium hydroxide solution for fifteen minutes. It was then centrifuge for ten minutes in a $500 \mathrm{ml}$ graduated cylinder. $5 \mathrm{ml}$ clear extract was added to $50 \mathrm{ml}$ with $30 \%$ sulphur salicylic acid solution. It was inverted several times and immediately the degree of turbidity at $450 \mathrm{~nm}$ in a $4 \mathrm{~cm}$ cell read against sulphur salicylic acid solution as instrument blank. The percentage protein content was determined using the equation as shown in equation (3).

252 — Ukrainian Journal of Food Science. 2016. Volume 4. Issue $2-$ 
where:

$\mathrm{Y} \quad=$ Calorimeter reading

$\mathrm{X} \quad=\%$ protein

Determination of Fat Content of Suya. This was carried out as described by [15]. $2 \mathrm{~g}$ of the Suya sample was stirred with $2 \mathrm{ml}$ of alcohol and then $7 \mathrm{ml}$ of concentrated hydrochloric acid and $3 \mathrm{ml}$ of water was added. The Suya sample was heated at about $80^{\circ} \mathrm{C}$ for about an hour. $10 \mathrm{ml}$ of alcohol was added to the cooled hydrolysed mixture followed by $25 \mathrm{ml}$ of light petroleum and the fat extracted three times of $25 \mathrm{ml}$ of the ether.

The percentage fat content was determined using the equation 4.

$$
\% \text { fat }=\frac{W_{1}-W_{2}}{W_{3}} \cdot 100,
$$

Where:

$\mathrm{W}_{1} \quad=$ Weight of Suya sample in the flask before removal of fat $(\mathrm{g})$

$\mathrm{W}_{2} \quad=$ Weight of Suya sample in the flask after removal of fat $(\mathrm{g})$

$\mathrm{W}_{3} \quad=$ Weight of Suya sample $(\mathrm{g})$

\section{Results and discussion}

It can be seen in Table 2 the effects of method of processing, packaging materials and hours of preservation on the proximate compositions (ash, moisture, crude protein and fat) using Analysis of Variance (ANOVA). To check the level of significance at $(\mathrm{p} \leq 0.05)$.

Table 2

Effects of method of processing (M), packaging materials $(\mathrm{P})$ and hours of preservation $(\mathrm{H})$ on the quality attributes of Suya meat.

\begin{tabular}{|l|l|l|l|l|l|l|l|}
\hline $\begin{array}{l}\text { Quality } \\
\text { attributes }\end{array}$ & $\mathbf{M}$ & $\mathbf{P}$ & $\mathbf{H}$ & $\mathbf{M} * \mathbf{P}$ & $\mathbf{M} * \mathbf{H}$ & $\mathbf{P} * \mathbf{H}$ & $\mathbf{M} * \mathbf{P} * \mathbf{H}$ \\
\hline Ash & 0.452 & $0.000^{*}$ & 0.734 & 0.721 & 0.886 & $0.000^{*}$ & 0.975 \\
\hline Moisture & 0.156 & $0.000^{*}$ & $0.002^{*}$ & $0.002^{*}$ & 0.233 & 0.308 & 0.360 \\
\hline $\begin{array}{l}\text { Crude } \\
\text { protein }\end{array}$ & $0.000^{*}$ & $0.001^{*}$ & $0.004^{*}$ & 0.467 & 0.634 & 0.830 & 0.830 \\
\hline Fat & $0.000^{*}$ & $0.000^{*}$ & $0.000^{*}$ & $0.000^{*}$ & 0.991 & 1.000 & 1.000 \\
\hline
\end{tabular}

* Significant at $\mathrm{p} \leq 0.05$

The analysis of variance test on Table 2 showed that the packaging materials (Paper, Cling film, Aluminum foil, Glass jar) are statistically significant on the dependent variables (ash, moisture, crude protein and fat) in which the p-values are $0.000,0.000,0.001$ and 0.000 which are less than 0.05 . Also the hours of preservation are statistically significant on the dependent variables (moisture, crude protein and fat) in which the p-values are 0.002 , 0.004 and 0.000 which are less than 0.05 . Meanwhile the interaction between the two study parameters $(\mathrm{P}$ and $\mathrm{H})$ were also statistically significant on the dependent variable ash in 
which the p-value is 0.000 and the interaction between the two study parameters ( $\mathrm{M}$ and $\mathrm{P}$ ) were also statistically significant on the dependent variable (moisture and fat) in which their p-values are 0.002 and 0.000 which are less than 0.05 .

From Table 2 It can be inferred that all the variables of interest, method of processing, packaging materials (Paper, Cling film, Aluminum, Glass jar) and hours of preservation were statistically significant on all the dependent variables; ash, moisture, crude protein and fat except ash in which the method of processing and hours of preservation do not have any significant effect. Table 3 showed the multiple comparisons for packaging materials using Duncan's New Multiple Range Test (DNMRT).

Table 3

Multiple comparison using the Duncans' New Range Test for packaging materials

\begin{tabular}{|l|l|l|l|l|l|}
\hline \multirow{2}{*}{$\begin{array}{l}\text { Quality } \\
\text { attributes }\end{array}$} & \multicolumn{4}{|c|}{ Packaging materials } \\
\cline { 2 - 6 } & Glass jar & $\begin{array}{l}\text { Aluminium } \\
\text { foil }\end{array}$ & Cling film & Paper & Control \\
\hline Ash & $6.4212^{\mathrm{a}}$ & $6.2474^{\mathrm{a}}$ & $5.4476^{\mathrm{b}}$ & $5.2831^{\mathrm{b}}$ & $5.3450^{\mathrm{c}}$ \\
\hline Moisture & $8.0560^{\mathrm{b}}$ & $8.1679^{\mathrm{a}}$ & $7.3343^{\mathrm{b}}$ & $8.1252^{\mathrm{a}}$ & $5.3400^{\mathrm{c}}$ \\
\hline $\begin{array}{l}\text { Crude } \\
\text { protein }\end{array}$ & $40.1800^{\mathrm{a}}$ & $38.7879^{\mathrm{a}}$ & $38.4605^{\mathrm{b}}$ & $37.9250^{\mathrm{c}}$ & $38.3033^{\mathrm{c}}$ \\
\hline Fat & $10.6881^{\mathrm{a}}$ & $9.8383^{\mathrm{c}}$ & $10.1660^{\mathrm{c}}$ & $11.6129^{\mathrm{a}}$ & $12.3933^{\mathrm{a}}$ \\
\hline
\end{tabular}

Mean with the same alphabet are not significantly different from each other.

The Duncan New Multiple Range Test (DNMRT) for packaging materials on Table 3 showed the different mean values of the quality attribute in the materials. It can be inferred from Table 2 that the mean ash of Suya in Glass jar was 6.42 and Aluminium foil was 6.27 and were significantly higher than those in Cling Film of 5.45 and paper of 5.28. Ash refers to any inorganic material such as minerals, present in food; it is called ash because it is the residue that remains after heating removes water and organic materials such as fat and protein. The variation in the ash content may be as a result of the properties of the various packaging materials. The permeability of packaging materials is of importance in retaining the desirable nutrients or in permitting undesirable components to permeate through the Packaging materials from the ambient temperature [17].

The mean moisture of Suya in paper was 8.13 and was significantly higher than those in Glass jar which was 8.06, Aluminium foil was 8.16 and Cling Film was 7.33. Moisture refers to the presence of a liquid especially water in trace amount. A higher increase of moisture in paper is due to the highly porous cellulose fibers of paper, they readily absorb moisture from their environment or in contact with the food as reported by [18]. The decrease in moisture content of Glass jar, Aluminium foil may be as a result of their impermeability to gas and water. Moisture rich foods are easily susceptible to microbial attack which can affect the quality of the food material. The mean crude protein of Suya in Glass jar was 40.18 and Aluminium foil was 38.79 which were significantly higher than those in Cling Film which was 38.46 and 37.93 in paper. The high Crude protein content agrees with [19] who reported that meat with intermediate moisture contents are less bulky and have higher protein than those with high moisture content. The impermeablity properties of Glass jar and Aluminium foil brings about a variation in the crude protein content when compared to Cling film and Paper that has low permeability. 
The mean fat of Suya in Paper was 11.61 and was significantly higher than those in Cling Film with a value of 10.17 and Aluminium foil has a value 9.84 while sample stored in Glass jar has a mean value of 10.69. An increase in the fat content of Suya in paper may be as a result of possible hydrolysis reaction due to the action of lipolytic enzymes or moisture [20]. Paper is not a good packaging material because it has poor barrier properties and they readily absorb moisture and air from their environment or in contact with the food. Oxidation of fat causes rancidity in food.

It was also found that the hours of preservation had effects on the moisture content of the stored samples as shown in Table 4, an increase in the hours of preservation leads to an increase in moisture content and crude protein but decrease in fat content of the samples.

Table 4

Multiple comparison using the duncan new range test for hours

\begin{tabular}{|l|l|l|l|}
\hline \multirow{2}{*}{$\begin{array}{l}\text { Quality } \\
\text { attributes }\end{array}$} & \multicolumn{3}{|c|}{ Time of preservation (hours) } \\
\cline { 2 - 4 } & $\mathbf{6}$ & $\mathbf{1 2}$ & $\mathbf{1 8}$ \\
\hline Moisture & $7.5979^{\mathrm{b}}$ & $7.8633^{\mathrm{a}}$ & $8.0148^{\mathrm{a}}$ \\
\hline Crude Protein & $38.4490^{\mathrm{b}}$ & $38.8633^{\mathrm{a}}$ & $38.8660^{\mathrm{a}}$ \\
\hline Fat & $10.7879^{\mathrm{a}}$ & $10.6802^{\mathrm{b}}$ & $10.6183^{\mathrm{b}}$ \\
\hline
\end{tabular}

Mean with the same alphabet are not significantly different from each other.

Method of processing also has effect on the quality of the processed samples. Table 5 shows the mean crude protein of Suya using the roasting technique and the value was 41.82 which was significantly higher than that of the grilling technique of 39.92 value. Roasting refers to cooking food in an oven with dry heat. Most nutrient losses are minimal with this cooking method [11]. The decrease in the crude protein content using the grilling technique is due to the fact that grilling is one of the most popular cooking methods because of the great flavour it gives, However up to forty percent of nutrients may be lost during grilling when the nutrient rich juice drops from the meat [11].

The decrease in the fat content using the grilling technique is due to the fact that grilling is usually considered as a low fat cooking method because it renders out food's internal fat during the grilling process. Also grilled meats have a reduced fat content because the fat drips off as the meat is grilled [13].

Table 5

Multiple comparisons using the duncan new range test for method of production

\begin{tabular}{|l|l|l|}
\hline \multirow{2}{*}{$\begin{array}{l}\text { Quality } \\
\text { Attributes }\end{array}$} & \multicolumn{2}{|c|}{ Processing techniques } \\
\cline { 2 - 3 } Crude Protein & Roasting & Grilling \\
\hline Fat & $41.8206^{\mathrm{a}}$ & $39.9192^{\mathrm{b}}$ \\
\hline
\end{tabular}

Mean with the same alphabet are not significantly different from each other. 


\section{Conclusions}

The following conclusions can be drawn from the result obtained in the course of this study:

1. Processing methods used in the preparation of Suya meat for consumption have effects on the quality attributes of the final products as the crude protein and fat content of roasted meat were 41.82 and 9.92 respectively which were significantly higher than that of the grilled meat which were 39.92 and 8.36 respectively. The use of roasting technique produced better products when compared with grilling technique.

2. Packaging materials have effects on the quality attributes of the final products of Suya meat during storage due to variation in their properties, as the results show that crude protein and ash contents of samples stored in Glass Jar and Aluminium foil were higher than those stored in Cling film and Paper. Results show that samples stored in Glass jar and Aluminium foil have higher qualities and were not found to be significantly different from each other but were significantly different from those stored in Cling film and Paper which were of lower qualities. Therefore in order to obtain the best quality of processed meat, Suya meat is to be stored in Glass jar or Aluminium foil. Further research should be focussed on improvement of Cling film and Paper for handling Suya meat during storage as they are considered to be more economical and affordable as compared to Glass jar and Aluminium foil which are more expensive.

\section{References}

1. Alonge D.O., Hiko, A.A. (1981), Traditional methods of meat preservation and preparation in Nigeria, West Africa farm food proceedings, pp. 19-21.

2. Judge D. M., Robert A. M., Morris M. (2002), Preparation of Suya in Africa, Journal of African foods. (20), pp. 52-55.

3. Rokade M. M., Rokade P. R., Thakare S. R., Rupvate N. B., Mahale I., Sanjay, R. C. (2012), Formulation design and evaluation of transdermal film of Losartan Potassium using hydrophilic and hydrophobic polymers. American Journal of PharmTech Research.8, pp. 22-28.

4. Marsh K., Bugusu B. (2007), Food packaging- roles, materials and environmental issues, Journal of Food Science, (72), pp. 23-36.

5. Chin, K.B., Han, S., Ramachandraiah, K. (2015), Nanotechnology in Meat Processing and Packaging: Potential Application -A Review. Asian-Australasian Journal of Animal Sciences, 28(2), 290-302. DOI: https://doi.org/10.5713/ajas.14.0607

6. Uzeh, R.E and Akinyemi, M.O (2012), Microbiological and physico-chemical characteristics of stored Tsire-Suya, a roasted meat product. International Journal of Biological Chemical Science (4), 1804-1809.

7. Coles R. (2003), Food packaging technology, London, Blackwell publishing CRC press pp. 1-31.

8. Lockamy A. (1995), A conceptual framework for assessing strategic packaging decisions, International Journal of Logistics Management, 6, pp. 51-60.

9. Lamberti M., Esher F. (2007), Aluminium foil as a food packaging material in comparison with other materials, Journal of food Packaging Material,pp. 23, 407-433.

10. Page B., Edwards M., May N. (2003), Food Packaging technology, London, U.K. Blackwell Publishing, CRC Press. pp 12-51. 


\section{— Food Technologies}

11. Franziska S. (2012), How cooking affects the nutrient content of food, https://authoritynutrition.com/cooking-nutrient-content/.

12. Floros J. D., Dock L. L., Han J. H. (1997), Active packaging technologies and applications, Food Cosmet Drug Packag, 20, pp.10-7.

13. Becker F. (2014), The difference in roasting and grilling, available at: http://www.livestrong.com/article/457331-recommended-way-to-cook-bonelesssirloin-roast-beef/.

14. Adeyeye S. A. (2017), The role of food processing and appropriate storage technologies in ensuring food security and food availability in Africa, Nutrition and Food Science, 47(1), pp. 35-42.

15. Jekayinka S., Omisakin O. (2005), The energy potentials of some agricultural wastes as local fuel materials in Nigeria, Agricultural Engineering International Journal, (7).

16. AOAC (2000), Official method of analysis of the Association of Official Analytical Chemists, 15th Edition, Washington USA.

17. Floros J. D., Matsos K. I. (2005), Introduction to modified atmosphere packaging, In, Han J. H., editor. Innovations in Food Packaging, London, Elsevier Ltd., pp. 159-72.

18. Jong W.R. (2010), Effect of moisture content on tensile properties of paper based food packaging materials, Journal of Food Science and Biotechnology, (19), pp. 243-247.

19. Egbuike G.N., Okunbanjo A.O. (2000), Effects of processing on the quality of Nigerian meat products, Livestock production science, 59, pp.155-163.

20. Velasco J., Marmesat S., Dobarganes M.C. (2008), Chemistry of frying in deep fat, Frying of Foods, pp. 35-36. 